dr n. med. Arkadiusz Trzos ${ }^{1}$

mgr Katarzyna Długosz ${ }^{1}$

\title{
Wpływ wybranych elementów czasu reakcji systemu ratownictwa medycznego na efektywność udzielania pomocy ofierze wypadku komunikacyjnego ${ }^{2}$
}

\author{
Influence of Selected Elements Affecting Response Time for the Emergency Medical \\ System and the Effectiveness of Administering Aid to Victims of Road Traffic Accidents
}

\author{
Влияние отдельных элементов времени реакции системы неотложной \\ медицинской помощи на эффективность предоставления помощи жертвам ДТП
}

\begin{abstract}
ABSTRAKT
Cel: Celem pracy jest przedstawienie zależności pomiędzy wybranymi elementami wpływającymi na czas reakcji systemu ratowniczego a możliwością udzielania pomocy poszkodowanym w wypadkach komunikacyjnych.

Wprowadzenie: Wypadki komunikacyjne są jedną z najczęstszych przyczyn zgonów w krajach wysokorozwiniętych. Trwająca od lat restrukturyzacja systemu ratownictwa w Polsce ma na celu poprawienie efektywności służb ratowniczych. Ciągłej modyfikacji podlegają elementy, które wpływają na czas reakcji sytemu ratowniczego. Jednak zależność pomiędzy czasem reakcji systemu ratowniczego a efektywnością działań ratowniczych nie jest jedynym czynnikiem, który wpływa na przeżywalność ofiar wypadków. Szereg czynników, determinujących przebieg zdarzenia, wpływa choćby na zakres możliwej do udzielenia pomocy medycznej. Pozycjonowanie sił i środków, transmisja danych on-line, zaangażowanie wolontariuszy, teletransmisja danych o stanie pacjenta w trakcie transportu do szpitala zmieniają możliwości reagowania systemu ratowniczego. Integracja Krajowego Systemu Ratowniczo-Gaśniczego (KSRG) z systemem Państwowe Ratownictwo Medyczne (PRM) w Polsce wpływa na wzrost skuteczności reagowania systemu ratowniczego w pierwszych minutach od zdarzenia, zaś potencjał niezrzeszonych wolontariuszy i organizacji ochotniczych (np. Ochotnicza Straż Pożarna, OSP) jeszcze bardziej zwiększa możliwości systemu ratownictwa medycznego, dzięki skróceniu czasu reakcji i udzieleniu pomocy poszkodowanym w możliwie najkrótszym czasie.

Metodologia: Na potrzeby pracy opisano czynniki, biorące udział w określaniu efektywności pracy sił systemu ratownictwa medycznego. Wzięto pod uwagę: czas reakcji systemu ratownictwa medycznego (także pierwszej pomocy i kwalifikowanego ratownictwa), zakres udzielonej pomocy, zdolności diagnostyczne w rozpoznawaniu obrażeń doznanych w wyniku wypadku (szczególnie rozpoznawanie i leczenie zatrzymania krążenia). Sprawdzano wpływ tych czynników na efektywność udzielania pomocy ofiarom wypadków komunikacyjnych. Wnioski: Integracja systemów PRM i KSRG, wsparcie ze strony świadków zdarzenia i ratowników wolontariuszy, a także wykorzystanie nowoczesnych rozwiązań teleinformatycznych wpływa na wzrost efektywności udzielania pomocy ofiarom wypadków komunikacyjnych poprzez skrócenie czasu reakcji systemu ratowniczego.
\end{abstract}

Słowa kluczowe: wypadki komunikacyjne, „złota godzina”, „trimodalny rozkład zgonów” Trunkey’a, czas reakcji, ratownictwo medyczne Typ artykułu: artykuł przeglądowy

\section{A BSTRACT}

Aim: The purpose of this study is to reveal the relationship between selected elements, which influence the response time of the rescue system, and the possibility of administering aid to the injured in traffic accidents.

Introduction: Traffic accidents are one of the leading causes of death in developed countries. Many years of restructuring the rescue system in Poland was aimed at increasing the effectiveness of emergency rescue services. Elements exposed to constant modification

\footnotetext{
Uniwersytet Jagielloński - Collegium Medicum, Kraków / Jagiellonian University - Medical College, Cracow, Poland; arkadiusztrzos@gmail.com;

2 Wkład merytoryczny w powstanie artykułu / Percentage contribution: A. Trzos - 70\%, K. Długosz - 30\%;
} 
are ones which impact on the response time of the rescue system. However, the relationship between the response time of the rescue system, functioning in Poland in its present form, and the effectiveness of rescue operations is not the only factor, which impacts on the survival of accident victims. There are a number of other factors, which determine the course of events, as well as the extent of possible provision of medical assistance. Positioning of resources - human and equipment, "on-line" data transmission, commitment of volunteer personnel, monitoring and data transmission about the patients' condition during transportation to hospital are factors, which impact on the response capabilities of the emergency rescue system. Integration of the National Firefighting and Rescue System (NFRS) with Emergency Medical Services (EMS) in Poland, contributes to the effectiveness of the rescue system response during the first few minutes after an incident. Additional possibilities offered by volunteer organisations, such as Fire Service volunteers, will enhance further the capabilities of the medical rescue system, culminating in quicker reaction and provision of aid in possibly the shortest period of time. Methodology: Factors, which influence the effectiveness of the medical emergency system were analysed for the purpose of this research. The study took into account: reaction time of the emergency medical system (first aid and rescue by qualified personnel), scope of administered medical assistance, ability to diagnose injuries sustained in an accident (especially, diagnosis and treatment of a cardiac arrest). Research included a check on the influence of these factors, on the effectiveness of administering aid to victims of traffic accidents. Conclusions: Integration of Emergency Medical Services (EMS) and National Firefighting and Rescue System (NFRS), support from incident witnesses rescue volunteers, and the use of modern ICT solutions, improves effectiveness of aid to victims of road accidents by reducing the rescue system response time.

Keywords: road accidents, "golden hour”, Turnkey’s “Trimodal distribution of mortality”, reaction time, medical rescue services Type of article: review article

\section{АННОТАЦИЯ}

Цель: Целью исследования является представление зависимости между отдельными элементами, влияющими на время реакции системы спасения и возможностью предоставления помощи потерпевшим в ДТП.

Введение: ДТП являются наиболее распространенной причиной смерти в высокоразвитых странах. На протяжении многих лет продолжающаяся реструктуризация системы спасения в Польше направлена на повышение эффективности работы спасательных служб. Элементами, подвергающимися постоянной модификации, являются те, которые влияют на время реакции системы спасения. Однако, зависимость между временем реакции системы и эффективностью спасательных действий не является единственным фактором, который влияет на выживание пострадавших в ДТП. Ряд факторов, определяющих ход происшествий, влияет даже на диапазон оказания возможной медицинской помощи. Распределение сил и средств, передача данных онлайн, помощь волонтёров, теле-трансмиссия данных относительно состояния пациента во время его транспортировки в больницу - изменяют возможности реакции системы спасения. Интеграция Национальной Спасательно-Гасящей Системы (KSRG) с системой Государственной Службы Скорой Медицинской Помощи (РRM) в Польше, влияет повышение эффективности реакции системы спасения в течение первых минут после возникновения происшествия, а потенциал в виде независимых волонтёров и добровольных организаций (например Добровольной Пожарной Службы, ОSР) ещё более расширяет возможности системы медицинской помощи, за счёт сокращения времени реакции и предоставления помощи пострадавшим как можно скорее.

Методология: В исследовании описываются факторы, которые нужны для определения эффективности работы и службы медицинской помощи. Были приняты во внимание: время реакции системы медпомощи (в том числе оказания неотложной помощи и профессионального спасения), объем предоставленной помощи, потенциал при диагностике травм, полученных вследствие аварии (особенно диагностика и лечение проблем с остановкой кровообращения). Было проверено влияние этих факторов на эффективность предоставляемой помощи пострадавшим в ДТП.

Выводы: Интеграция систем PRM и KSRG, поддержка со стороны очевидцев происшествия и спасателей волонтеров (медиков), а также использование современных теле-информационных решений влияет на повышение эффективности предоставляемой помощи пострадавшим в ДТП благодаря сокращению времени реакции системы спасения.

Ключевые слова: ДТП, „золотой час”, „три-модульное распределение смерти (Turnkey)”, время реакции, служба скорой медицинской помощи

Вид статьи: обзорная статья

\section{Wprowadzenie}

Jedną z konsekwencji rozwoju cywilizacyjnego, która coraz częściej zwraca uwagę badaczy, jest ciągły wzrost liczby śmiertelnych ofiar wypadków komunikacyjnych oraz osób rannych i kontuzjowanych w ich wyniku. Każdego roku ponad $5 \mathrm{mln}$ ludzi na świecie umiera $\mathrm{z}$ powodu doznanych urazów. Już ponad dziesięć lat temu, w roku 2002, obrażenia u ofiar wypadków komunikacyjnych, obrażenia spowodowane samookaleczeniem, przemocą interpersonalną, oparzeniami i tonięciem stanowiły główną przyczynę zgonów pomiędzy 5 a 44 rokiem życia. Dodatkowo co roku miliony ofiar tego typu zdarzeń zostają wykluczone z normalnego życia z powodu powstałej niepełnosprawności. W przypadku braku opracowania i wdrażania nowych, bardziej skutecznych rozwiązań w systemie udzielania pomocy ofiarom wypadków, spodziewać się można dalszego wzrostu współczynnika śmiertelności w tej grupie osób. Niesprawnie zorganizowany system leczenia i rehabilitacji ofiar urazów wpływać będzie także na wzrost liczby osób niepełnosprawnych.

Wypadki niosą za sobą poważne skutki zarówno dla samej ofiary, jej rodziny, jak i całej społeczności, w której żyje osoba po wypadku. Niepełnosprawność nabyta w wyniku wypadków szczególnie negatywnie wpływa na funkcjonowanie rodziny poszkodowanego. $\mathrm{W}$ wielu 
przypadkach konieczność opieki nad osobą, która uległa wypadkowi, ogranicza możliwość wykonywania pracy przez członków jej rodziny w pełnym wymiarze godzin, a tym samym pozyskiwanie wystarczających środków do życia. W innych przypadkach zapewnienie opieki dla osoby niepełnosprawnej stanowi przyczynę obciążenia budżetu rodzinnego. Musi minąć wiele dni, miesięcy, a często nawet lat, by zarówno rodzina, jak i sama osoba niepełnosprawna dostosowała się do życia po wypadku, zaakceptowała nową, trudną dla wszystkich sytuację. Nie do pominięcia jest także fakt, iż wysoki koszt leczenia skutków urazów i rehabilitacji pacjenta są czynnikami, które wpływają na kondycję ekonomiczną całego kraju. Ogromna liczba ofiar wypadków komunikacyjnych wpływa więc na kształt i funkcjonowanie gospodarki państwa, głównie przez straty w obrębie zasobów ludzkich kraju.

Wypadki komunikacyjne skutkujące obrażeniami ciała bądź śmiercią ofiar, na których skupiono się w niniejszym opracowaniu, nie są zjawiskiem przypadkowym, którego nie można przewidzieć. Otóż wiele przyczyn wypadków można zidentyfikować, co umożliwia wdrożenie działań, mających na celu ich uniknięcie, bądź choćby ograniczenie ich liczby i skutków. W przeciągu ostatnich kilku dekad wykazano, że wielu wypadkom, tym samym związanym z nimi urazom, można zapobiec, wdrażając odpowiednie rozwiązania profilaktyczne. Przykładem takich prostych działań może być nakaz stosowania kasków ochronnych przez motocyklistów i rowerzystów, obowiązek zapinania pasów bezpieczeństwa w samochodach, ograniczenia prędkości lub używanie fotelików do przewożenia dzieci.

W niniejszym artykule zwrócono uwagę na elementy, które wpływają na czas reagowania służb ratowniczych na powstałe już zdarzenie. Opisano czynniki wpływające na przeżywalność ofiar wypadków, których potencjalna zdolność do przeżycia otwiera drogę do prowadzenia przez służby ratownicze efektywnych działań.

\section{Wypadki komunikacyjne w Polsce ${ }^{3}$}

Wskaźniki urazowości wśród hospitalizowanych pacjentów są wysokie zarówno w krajach wysoko rozwiniętych, jak i tych obecnie rozwijających się. W Polsce przyczyny urazów, to te charakterystyczne dla obu powyższych grup. Jak podaje L. Brongel, w Polsce rocznie ponad 3 miliony osób doznaje obrażeń ciała. $\mathrm{Z}$ tej liczby blisko 350 tys. osób jest hospitalizowanych. Co roku także, w wyniku doznanych urazów, umiera w Polsce ok. 30 tys. osób [1]. Kontynuując analizę dostępnych statystyk, zauważa się, iż wypadki komunikacyjne stanowią w Polsce jedną z głównych przyczyn zgonów osób w młodym wieku. Według danych Komendy Głównej Policji, w 2013 roku doszło do 35847 wypadków drogowych. W wypadkach tych zginęło 3357 osób, zaś 44059 zostało rannych. Mimo, iż w ostatnich latach liczba wypadków komunikacyjnych, a tym samym także liczba ofiar śmiertelnych systematycznie spada, nadal utrzymuje się ona na wysokim poziomie. Liczbę wypadków komunikacyjnych w Polsce w latach 2003-2013 przedstawiono na rycinie 1.

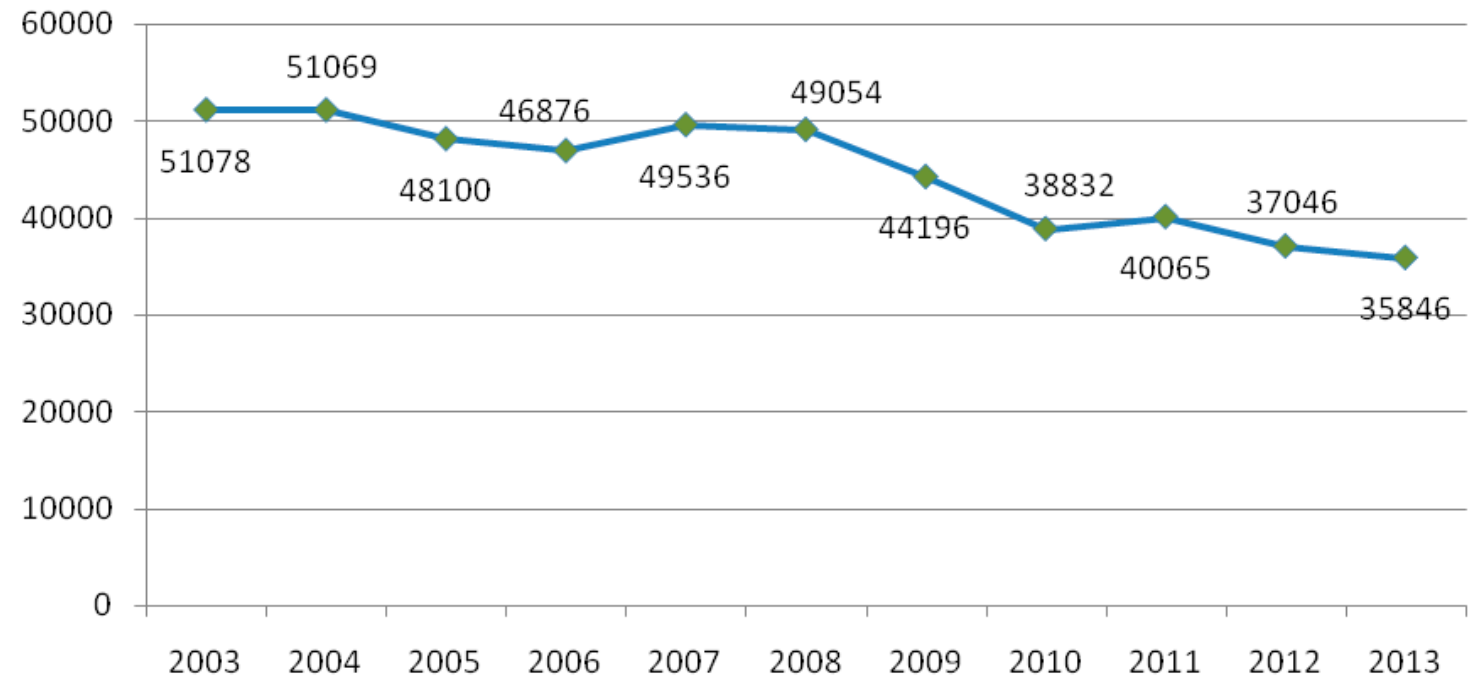

Ryc. 1. Wypadki drogowe w Polsce w latach 2003-2013

Fig. 1. Road accidents in Poland in 2003-2013

Źródło: Opracowanie własne na podstawie danych statystycznych Komendy Głównej Policji (www. policja.pl/statystyki). Source: Own elaboration based on the statistics from the Police (www. policja.pl/statystyki).

Ze statystyk dotyczących 2012 roku wynika, iż zdecydowana większość wypadków, bo 26078 (72,7\% ogólnej liczby wypadków) miała miejsce w obszarze zabudowanym. Zginęło w nich 1581 osób, zaś 30935 zostało rannych. Poza

\footnotetext{
Opracowane na podstawie danych statystycznych Komendy Głównej Policji (www. policja.pl/statystyki)
}

obszarem zabudowanym doszło do 9769 wypadków (27,3\% ogółu), zginęło w nich 1776 osób, a obrażeń ciała doznało 13124 uczestników ruchu. Spośród wszystkich rodzajów wypadków drogowych na pierwsze miejsce pod względem częstości występowania wysuwają się te, które zakwalifikować można do kategorii „zderzenie się pojazdów w ruchu”. W 2013 roku odnotowano 18184 takich wypadków, co 
stanowiło 50,7\% ogółu. W ich następstwie śmierć poniosło 1321 osób (39,4\% wszystkich ofiar wypadków), ranne zaś zostały 24743 osoby (56,2\% ogółu rannych w zdarzeniach komunikacyjnych). Kolejnym najczęściej występującym typem wypadku komunikacyjnego w Polsce w 2012 roku było „najechanie na pieszego”. Takie zdarzenia stanowiły 25,8\% ogólnej liczby wypadków (9 266 przypadków), w ich wyniku zginęło 1130 osób (33,7\% wszystkich ofiar wypadków), a 8701 zostało rannych (19,7\% ogółu). Z powyższych danych wynika, że Polska jest krajem, w którym wskaźnik śmiertelności w wypadkach drogowych jest jednym z najwyższych w Europie i wynosi 10,5. Dla porównania, w Niemczech i w Wielkiej Brytanii wynosi on 1,2. Zatem, w Polsce w wyniku doznanych obrażeń umiera prawie dziesięć razy więcej osób niż w krajach wysokorozwiniętych Europy Zachodniej.

Dopatrując się przyczyn wysokiej śmiertelności pacjentów wypadkowych w Polsce, można wymienić wiele czynników wpływających na taki stan rzeczy. Nie można w tym miejscu wykluczyć, iż jednym z nich jest działanie systemu ratownictwa medycznego w Polsce, który w niewystarczającym stopniu udziela pomocy osobom poszkodowanym w wypadkach. Bez przeprowadzenia szczegółowej analizy przyczyn zgonów nie można jednak dać jednoznacznej odpowiedzi o przyczynach tak dużej skali śmiertelności wśród ofiar wypadków. Mimo to niewątpliwie w każdym systemie ratowniczym są elementy, nad którymi warto pracować w celu podniesienia efektywności działań, do których został on powołany.

Każdy wypadek jest inny. To co nadaje specyfikę każdemu $\mathrm{z}$ nich, to przede wszystkim inne okoliczności zdarzenia, jego miejsce, przyczyny, liczba uczestników, czy też reakcja świadków. Mimo wymienionych czynników różnicujących, dopatrzyć się można także cech wspólnych dla wypadków komunikacyjnych, które jednocześnie pozwalają na dokonanie swego rodzaju kwalifikacji. Na ich podstawie, na potrzeby służb ratowniczych, wypadki podzielono na:

- wypadek jednostkowy - charakteryzujący się udziałem jednej ofiary, której przybyły na miejsce zdarzenia zespół ratowniczy udziela pomocy w sposób rutynowy, zgodnie z obowiązującymi w danym kraju standardami postępowania;

- $\quad$ wypadek mnogi - charakteryzujący się udziałem więcej niż jednej ofiary, którym przybyłe na miejsce zespoły ratownicze udzielają pomocy w sposób rutynowy, zgodnie z obowiązującymi standardami;

- wypadek masowy - charakteryzujący się udziałem więcej niż jednej ofiary. W przebiegu takiego zdarzenia, poszkodowanym, będącym w stanie zagrożenia życia, służby ratownicze nie są w stanie udzielić pomocy w sposób rutynowy. Stosują tym samym w swoim postępowaniu uproszczenia i dopuszczalne kompromisy medyczne;

- katastrofa - specyficzny rodzaj zdarzenia, którego rozmiary i liczba poszkodowanych oraz ciężkość ich obrażeń przekraczają możliwości i zakres działań rutynowo wykonywanych przez systemy ratownicze. Skutki i obrażenia poszkodowanych nie mogą być zabezpieczone przy wykorzystaniu rutynowo dostępnych sił i środków. W celu opanowania sytuacji konieczne jest więc uzyskanie pomocy z zewnątrz [2].

Możliwości służb w zakresie prowadzenia działań ratowniczych w poszczególnych typach zdarzeń są różne. Mimo przybycia zespołów poszczególnych służb na miejsce zdarzenia, dostęp do wszystkich poszkodowanych może być ograniczony i wynika on ze specyfiki danego zdarzenia. Zatem także czas rozpoczęcia medycznych czynności ratunkowych będzie warunkowany przez charakter zdarzenia i będzie on różny.

\section{3. „Złota godzina” $i$,trimodalny rozkład zgonów" Trunkey'a jako koncepcje warunkujące kształt systemów ratownictwa medycznego na świecie}

Niestety jak dotąd zasady tworzenia i funkcjonowania systemów ratownictwa medycznego poszczególnych krajów świata opierają się niejednokrotnie o kryteria, które nie mają związku z wynikami przeprowadzonych badań naukowych. Zwykle głównymi warunkami wyboru modelu organizacyjno-funkcjonalnego systemów ratownictwa są wyobraźnia, intuicja, doświadczenia innych krajów, czy choćby entuzjazm osób odpowiedzialnych za ich współorganizowanie [3]. Wiele z założeń, na podstawie których tworzono systemy ratownicze w przeszłości, jest obecnie kwestionowanych, co wynika głównie z troski o los pacjenta. Drugą przesłanką dla wprowadzania zmian w tym zakresie, w krajach takich jak Polska, jest presja kontroli kosztów w każdej dziedzinie ochrony zdrowia, chęć uniknięcia eskalacji wydatków na ratownictwo medyczne. Dotąd jednak zmiany wynikające z powyższych pobudek nie przynoszą spodziewanych efektów, a dodatkowo nie wpływają na ograniczanie śmiertelności wśród pacjentów urazowych.

Do tej pory na sposób organizacji systemu ratownictwa medycznego przedszpitalnego i szpitalnego wpłynęły $\mathrm{w}$ realny sposób dwie koncepcje. Pierwsza $\mathrm{z}$ nich dotyczy tzw. „złotej godziny” i podkreśla znaczenie wczesnej interwencji chirurgicznej u pacjentów, u których doszło do urazu. Pierwotnie owa teoria odnosiła się do ratownictwa przedszpitalnego, gdyż spora część czasu zawartego we wspomnianej „złotej godzinie” upływała przed momentem, w którym pacjent znalazł się w szpitalu [4]. $\mathrm{W}$ wielu zdarzeniach przyczyną takiego stanu rzeczy jest utrudniony dostęp do poszkodowanego. W myśl koncepcji "złotej godziny” konieczne jest minimalizowanie czasu, w którym pacjent pozostaje poza opieką specjalistyczną, co ma służyć zmniejszeniu wskaźnika śmiertelności wśród ofiar wypadków. Trzeba przy tym jednak pamiętać, iż na skalę ofiar śmiertelnych system ratownictwa medycznego może wpłynąć jedynie w przypadkach pacjentów, u których wdrożenie odpowiednich procedur medycznych jest w stanie zapobiec ich śmierci [5]. Druga z koncepcji to tzw. „trimodalny rozkład zgonów” wśród osób, które doznały urazu, opracowany przez D. Trunkey'a w 1983 roku [6]. Zasugerował on w swoich badaniach, że w zdarzeniach takich jak wypadki komunikacyjne, połowę ofiar śmiertelnych stanowią osoby, u których zgon nastąpił już na miejscu 
zdarzenia jako efekt doznanego urazu śmiertelnego. Do drugiej grupy, stanowiącej 30\% wszystkich śmiertelnych ofiar wypadków, Trunkey zaliczył osoby, które zmarły w czasie do 4 godzin po wypadku, zaś ostatnia grupa, obejmująca $20 \%$ z ogółu, to osoby zmarłe po 4 godzinach od momentu wystąpienia urazu.

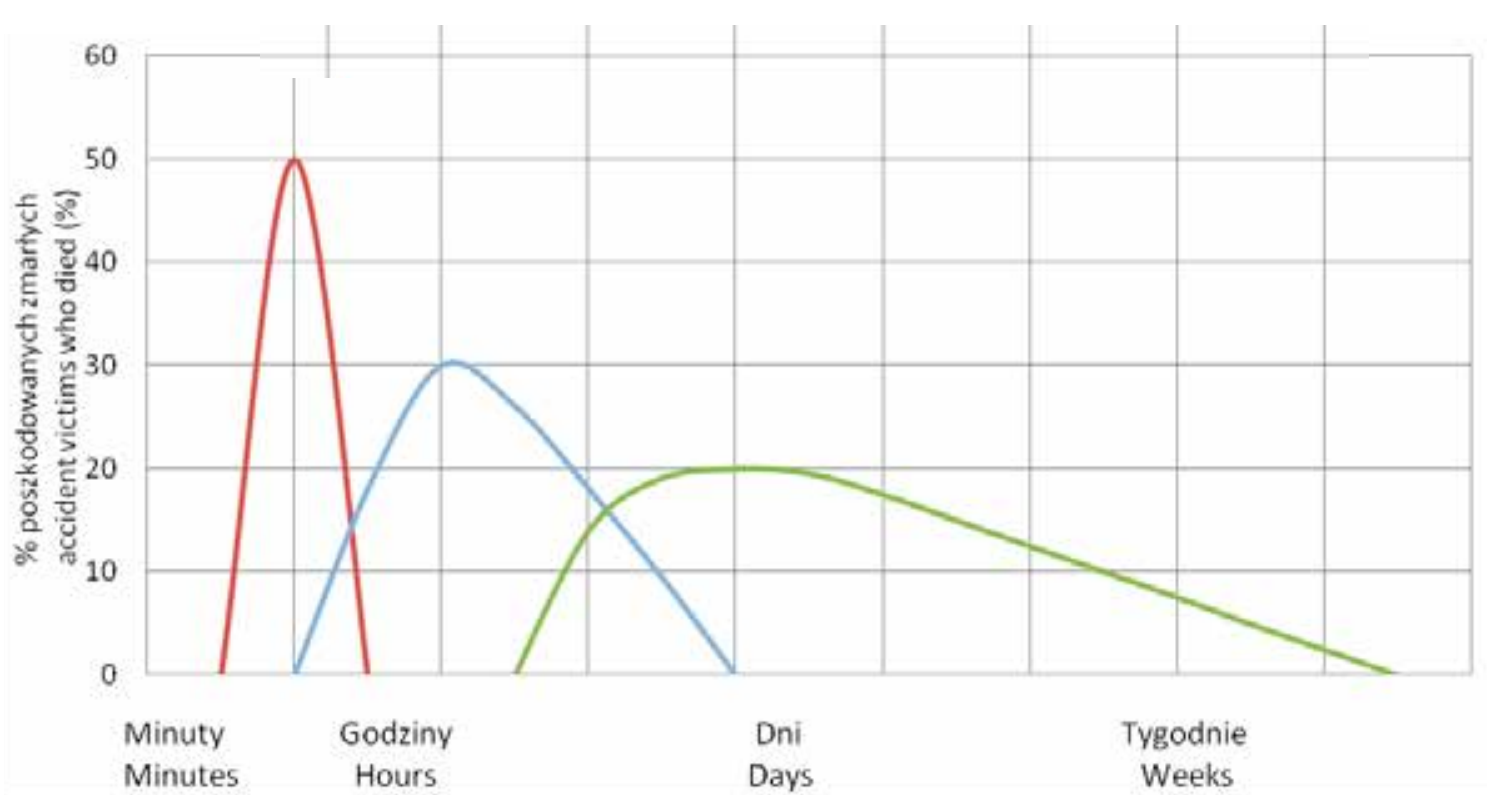

Ryc. 2. Trimodalny rozkład zgonów wg Trunkey’a

Fig. 2. Trunkey's Trimodal distribution of mortality

Źródło: Opracowanie własne na podstawie: Trunkey D.D., Trimodal distribution of mortality following a major trauma,

“Trauma. Sci Am” Vol. 249 Issue 2, 1983, pp. 20-7.

Source: Own elaboration based on: Trunkey D.D., Trimodal distribution of mortality following a major trauma,

“Trauma. Sci Am” Vol. 249 Issue 2, 1983, pp. 20-7.

Możliwości i zakres pomocy przedszpitalnej udzielanej osobom zakwalifikowanym przez Trunkey'a do poszczególnych grup jest różny. W grupie pierwszej zgon następuje natychmiast lub w bardzo krótkim czasie od momentu doznania urazu. W tym przypadku zgon może być wynikiem urazu śmiertelnego, obrażeń wtórnych, niedrożności dróg oddechowych bądź wykrwawienia. Możliwości efektywnego działania profesjonalnych służb są w tej grupie mocno ograniczone. W takich przypadkach najlepsze wyniki w zakresie ograniczania śmiertelności może przynieść działanie świadków zdarzenia, jego uczestników, którzy rozpoczną prowadzenie podstawowych zabiegów resuscytacyjnych (ang. Basic Life Support, BLS) na miejscu zdarzenia.

W grupie drugiej, którą wyróżnił Trunkey, zgon następuje w czasie liczonym w godzinach od momentu doznania urazu, również jako konsekwencja śmiertelnych obrażeń, nieudzielania właściwej pomocy bezpośrednio po urazie, nieadekwatnej do potrzeb pomocy medycznej, braku wystarczającej diagnostyki i leczenia na etapie ratownictwa szpitalnego.

W trzeciej grupie, zgon następuje w kilka dni od doznania urazu, jako konsekwencja niedostatecznej lub niepoprawnej diagnostyki i leczenia, infekcji, niewydolności wielonarządowej i innych powikłań. To również u tych pacjentów decyzje zapadające na miejscu wypadku, w czasie transportu i w szpitalnym oddziale ratunkowym mogą mieć podstawowe znaczenie dla dalszego przebiegu choroby [7]. Głównym problemem w tym zakresie jest niewydolność wielonarządowa (ang. multiorgan failure, MOF). Może ona powstać w wyniku takich zaburzeń jak: niedotlenienie, niedokrwienie, potem zaś powikłania związane z reperfuzją, zapalna reakcja ustroju na uraz (ang. systemic inflammatory response syndrome, SIRS), deficyt immunologiczny (ang. later compensatory counter-inflammatory response), upośledzenie funkcji poszczególnych narządów [8]. Obecnie nie dysponując zbyt wieloma możliwościami leczenia rozwiniętej MOF, można jedynie starać się jej zapobiec [9].

Dwie ostatnie grupy $\mathrm{z}$ wyróżnionych przez Trunkey'a stanowią pacjenci, których stan po doznaniu urazu stwarza warunki, pozwalające na ich przeżycie, jeśli system ratownictwa przedszpitalnego i szpitalnego zadziała w sposób poprawny i wdroży odpowiednie, dobrze zadysponowane leczenie specjalistyczne. O skuteczności leczenia tych pacjentów decyduje wiele czynników. Część z nich jest zależnych od funkcjonowania sytemu przedszpitalnego ratownictwa medycznego, inne stanowią wyzwanie dla lecznictwa specjalistycznego.

Wartym uwagi parametrem, który w pewnym sensie określa efektywność systemu ratownictwa medycznego, jest tzw. „odsetek zgonów do uniknięcia”. Analiza wyników badań, prowadzonych pod tym kątem, pokazała, iż ograniczenie liczby zgonów pacjentów, przed przyjazdem do szpitala, jest możliwe w $39 \%$ przypadkach [10], inne badania mówią o nawet 47\% [11]. Tych optymistycznych wyników nie potwierdzają jednak inne badania, prowadzone Wielkiej Brytanii. Badania te jednak dotyczyły węższej grupy, którą stanowiły ofiary wypadków drogowych, a nie jak w poprzednich - ofiary szeroko pojętych urazów. Badania brytyjskie objęły 305 ofiar śmiertelnych wypadków drogowych, zaś ich wyniki pokazały, iż w tej grupie można 
było uniknąć w fazie przedszpitalnej jedynie 3,1\% zgonów [12]. Mimo różnicy grup badawczych, trudno wyprowadzić jednoznaczne wnioski co do możliwości i skali zgonów, których można uniknąć poprzez działania służb ratowniczych. Analizując wyniki powyższych badań, można przypuszczać, że rozbieżności w tym zakresie zależne są od mechanizmu, rodzaju i ciężkości urazów, których doznała ofiara. Dlatego też nie da się w pełni i ostatecznie określić wpływu działań podejmowanych $\mathrm{w}$ ratownictwie przedszpitalnym na zmniejszenie liczby ofiar śmiertelnych urazów. Wszelkie działania podejmowane w celu zmniejszania skali tzw. „zgonów do uniknięcia” mają pełne uzasadnienie, zarówno pod względem medycznym, jak i ekonomicznym, mimo ogromnych kosztów, które są jednak zdecydowanie mniejsze niż te będące skutkiem zgonów pacjentów. Dlatego więc, w dalszej części pracy, autorzy zwracają uwagę na czynniki, których możliwość modyfikacji pozwala na podnoszenie efektywności w zakresie ograniczania śmiertelności wśród pacjentów po urazach.

\section{Czas akcji ratunkowej}

Czas akcji ratunkowej wyraża się w przedziale pomiędzy momentem wystąpienia zdarzenia a momentem rozpoczęcia definitywnego zaopatrzenia pacjenta w szpitalnym oddziale ratunkowym (SOR) lub centrum urazowym (CU). W ratownictwie światowym powszechnie przyjęło się uważać ten okres za wspomnianą wcześniej „złotą godzinę" (ang. "Golden hour"), która w pierwszym założeniu miała trwać dosłownie 60 minut [13]. Pojęcie „definitywnego zaopatrzenia pacjenta" w ciągu pierwszej godziny od momentu wystąpienia zdarzenia włączone zostało do terminologii medycyny ratunkowej przed ponad 30-ma laty przez R. Adamsa Cowley’a. Jednak wpływ czasu na wyniki leczenia i przeżywalność pacjentów zauważyli już podczas I wojny światowej francuscy chirurdzy wojskowi. Wzorując się na doświadczeniach wojennych, przede wszystkim wojnie koreańskiej i wojnie w Wietnamie, w latach sześćdziesiątych i siedemdziesiątych zaczęto wdrażać do ratownictwa cywilnego rozwiązania wojskowe. Wtedy też upowszechniono w Stanach Zjednoczonych zasadę „bierz i pędź” (ang. "scoop and run”) i możliwość udziału w akcji ratowniczej śmigłowców ratunkowych.

Punktem wyjścia dla założenia, iż czas udzielenia pomocy wpływa na ograniczenie śmiertelności w grupie ofiar urazów, była myśl, że w przypadku ciężkiego urazu, którego konsekwencją jest krwawienie wewnętrzne, wymagane jest podjęcie szybkiej interwencji chirurgicznej. W takiej sytuacji szybki transport do szpitala jest priorytetem. Opóźnienie w transporcie do szpitala, w opinii wielu autorów, powinno być ograniczone do minimum. Takie podejście stało się podstawą organizacji systemu ratowniczego na całym świecie, jednocześnie także koresponduje ono z zasadą „złotej godziny”.

Czas udzielania pomocy nie jest jednak zależny jedynie od szybkości reagowania i działania systemu ratownictwa medycznego. Na rycinie 3 przedstawiano elementy tworzące okres „złotej godziny”.

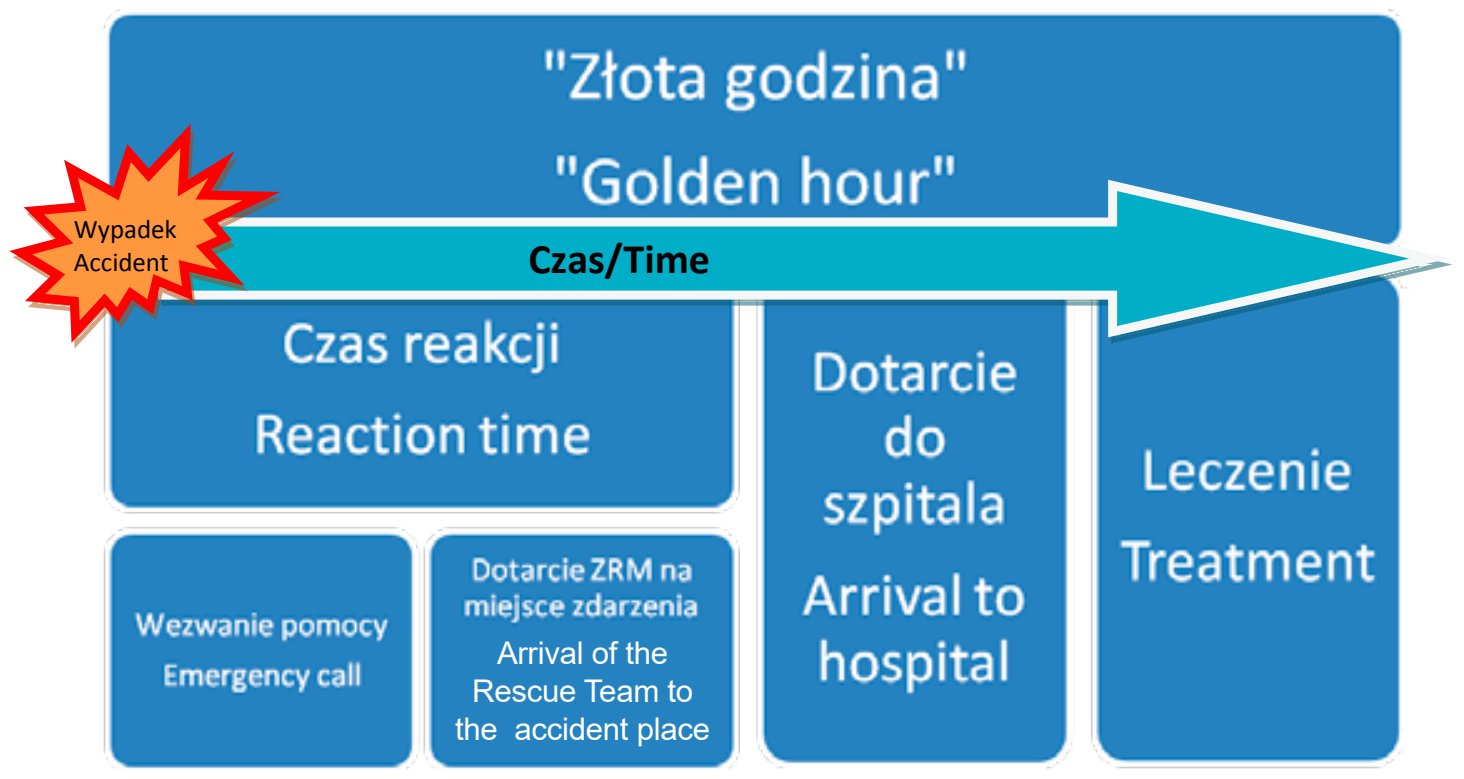

Ryc. 3. Elementy składowe „złotej godziny”

Fig. 3. Elements of the "golden hour"

Źródło: Opracowanie własne. Source: Own elaboration.

W pierwszym okresie po zdarzeniu świadkowie zdarzenia lub jego ofiary powiadamiają służby ratownicze. Od czasu, jaki upłynął pomiędzy momentem zaistnienia zdarzenia a chwilą przyjęcia i zweryfikowania zgłoszenia zależeć będzie zadysponowanie zespołów ratownictwa. Od tej chwili liczony jest czas reakcji systemu ratownictwa.
Czas reakcji zależny będzie więc od szybkości zadysponowania zespołu ratowniczego po przyjęciu zgłoszenia, czasu przygotowania zespołu do wyjazdu, czasu, który upływa podczas dojazdu na miejsce zdarzenia i dotarcie do pacjenta. Kolejnym wyróżnionym elementem wpływającym na czas reakcji jest czas poświęcony na triage, badanie 
"stay and play") [35]. W pierwszym modelu za podstawowe zadanie służb ratowniczych uznaje się jak najszybsze przetransportowanie pacjenta do oddziału ratunkowego, w którym wdrożone zostaną procedury ALS/ATLS (zaawansowane zabiegi po urazach, ang. Advanced Trauma Life Support) i zostanie mu udzielona pomoc lekarska. W drugim przypadku wstępna stabilizacja pacjenta odbywa się na miejscu zdarzenia, zespół ratownictwa medycznego przeprowadza badanie, zaopatruje obrażenia, itd. Szybki transport do szpitala może odbywać się pod opieką ratowników przeszkolonych w standardzie BLS lub ALS. Zatem zakres czynności możliwych do wykonania na miejscu zdarzenia oraz podczas transportu do szpitala będzie w takim wypadku różny. Może to zatem mieć w pewnych sytuacjach swoje konsekwencje dla pacjenta. $\mathrm{W}$ krajach europejskich istnieją również różnice w podejściu do udzielania pomocy pacjentom tzw. „urazowym”. W części krajów (Polska, Francja, Niemcy) w ratownictwie przedszpitalnym biorą udział lekarze, w innych (Holandia, Szwecja) system ratownictwa medycznego opiera się wyłącznie na ratownikach medycznych, jednak o różnym poziomie kompetencji. W środowisku eksperckim nieprzerwanie toczone są dyskusje, czy stosowanie w ratownictwie przedszpitalnym standardu ALS, w opozycji do szybkiego transportu, wpływa na zmniejszenie śmiertelności u pacjentów po urazie. Analiza wyników badań prowadzonych w tym zakresie, do tej pory nie pozwala na wydanie jednoznacznej opinii, jednak większość specjalistów skłania się ku zdaniu, iż stosowanie standardu ALS nie decyduje o przeżyciu pacjentów w urazach [36].

\section{Zatrzymanie krążenia w urazach}

Resuscytacja pozaszpitalna pacjentów z zatrzymaniem krążenia (ang. out-of-hospital cardiac arrest, OHCA) z przyczyn urazowych jest uważana przez wielu specjalistów medycyny ratunkowej za daremną, z powodu niskiej przeżywalności pacjentów, bądź poważnych zmian neurologicznych u tych, którzy przeżywają [37], [38-39]. Argumentem przeciwników resuscytacji w takich warunkach jest także fakt, iż każda tego typu akcja ratownicza generuje konieczność zaangażowania ogromnych środków ratownictwa, zarówno przedszpitalnego, jak szpitalnego - szpitalnego oddziału ratunkowego (SOR), oddziału intensywnej terapii (OIT) i oddziału chirurgii. The National Association of EMS Physicians oraz American College wypracowały wytyczne regulujące zasady prowadzenia i zaprzestania resuscytacji pacjenta urazowego w warunkach pozaszpitalnych [40]. Dokument ten budzi jednak spore kontrowersje i poddawany jest krytyce w środowisku ratowników medycznych i specjalistów medycyny ratunkowej. Wśród przeciwników powyższych zaleceń dominują ci, którzy posiadają pozytywne doświadczenia w resuscytacji pacjentów urazowych [41-42]. Jednak należy zauważyć, iż część materiału podważającego zalecenia amerykańskie, opiera się na doświadczeniach lekarskich. Nie jest więc on tożsamy z obszarem działania grupy techników medycznych (ang. Emergency Medical Technician, EMT), którzy w Stanach Zjednoczonych stanowią w dużym stopniu personel medyczny ambulansów [43-44].
Nagłe zatrzymanie krążenia (NZK), które współistnieje $\mathrm{z}$ urazami ma etiologię odmienną do tej dla NZK z przyczyn kardiologicznych. Pacjenci z zatrzymaniem krążenia w tych dwóch mechanizmach to dwie różne grupy. Różna więc jest także przeżywalność w tych grupach, którą warunkuje między innymi możliwość przeprowadzenia skutecznej resuscytacji. Badania prowadzone pod kierunkiem Deasy'a, w których analizie poddano przypadki zatrzymania krążenia w Australii w latach 2000-2009, wykazały, że spośród 33178 OHCA tylko w 2187 (6,6\%), przyczyną NZK był uraz. Świadkowie zdarzenia podjęli resuscytację w 201 przypadkach (10,2\%). Mediana czasu reakcji służb ratowniczych wynosiła $8 \mathrm{~min}$ (6-11 min). Analiza badanych przypadków wykazała, iż podstawowym zaburzeniem rytmu, powodującym zatrzymanie krążenia, była asystolia (1 650, 75,4\%), w następnej kolejności - aktywność elektryczna bez tętna (ang. Pulseless Electrical Activity, PEA) $(294,13,4 \%)$ i migotanie komór (ang. Ventricule Fibrillation, VF) (35, 1,6\%) [45]. Wnioski płynące z powyżej przywołanych badań pozwoliły stwierdzić, iż najważniejszym czynnikiem wpływającym na rokowanie pacjenta w OHCA jest występowanie migotania komór lub częstoskurczu komorowego bez tętna, jako przyczyny zatrzymania krążenia. Jeśli warunek ten jest spełniony, szanse przeżycia pacjenta w sytuacji podjęcia resuscytacji na miejscu zdarzenia, wzrastają 5-10-krotnie [46]. Każda minuta opóźnienia defibrylacji w takim wypadku zmniejsza prawdopodobieństwo przeżycia o 10-12\% [47,48]. Przeżywalność pacjentów z pozaszpitalnym zatrzymaniem akcji serca jest bardzo niska i, w zależności od badań, mieści się w przedziale 0-3,7\% [49]. Wspomniane zaś wcześniej badania z Australii wskazują na przeżywalność pacjentów na poziomie $5,1 \%$. Trudno jednoznacznie określić, gdzie tkwi przyczyna takiej różnicy w wynikach badań. Można stwierdzić, iż przeżywalność pacjentów z zatrzymaniem krążenia jest też różna, w zależności od rodzaju urazu, jakiego doznał. Jednak i w tym zakresie wyniki badań różnią się. W części $z$ nich wykazano, iż pacjenci $z$ urazem penetrującym mają większe szanse na przeżycie niż pacjenci z urazem tępym [50-51], inne badania przedstawiają odmienne wyniki [52]. Wnioskując, grupa pacjentów urazowych nie jest jednorodna, zaś mechanizm i rodzaj urazu nie są jedynymi czynnikami, które mają wpływ na przeżycie pacjenta z zatrzymaniem krążenia.

\section{Rola i zadania świadków zdarzenia}

Przebieg działań ratunkowych w fazie przedszpitalnej uzależniony jest od wielu czynników. W pierwszej kolejności wpływ na prowadzenie akcji ratunkowej ma reakcja świadków zdarzenia, którzy podejmą czynności ratunkowe i wezwą pomoc. To ich wezwanie uzależnia rozpoczęcie działań przez system ratownictwa. Osoby postronne mogą pomóc osobie poszkodowanej, udzielając jej pierwszej pomocy lub podejmując podstawowe czynności resuscytacyjne (BLS). Bezspornym pozostaje fakt, że prowadzenie BLS przed przyjazdem profesjonalnych zespołów ratownictwa jest jednym z niewielu czynności, które podnoszą wskaźnik przeżywalności wśród ofiar wypadków [53]. 
Zaangażowanie świadków zdarzenia w udzielanie pierwszej pomocy, zwłaszcza w prowadzenie resuscytacji krążeniowo-oddechowej w grupie pacjentów urazowych, jest niższe niż $w$ grupie pacjentów $z$ zatrzymaniem krążenia z przyczyn kardiologicznych. Na taki stan rzeczy prawdopodobnie znacząco wpływa specyfika zdarzenia i wygląd poszkodowanych po urazie. Przywołane wyżej badania Deasy’a wykazały, że w grupie poszkodowanych, którzy przeżyli, częstość prowadzenia resuscytacji BLS była wyższa niż w grupie ofiar śmiertelnych (21,4\% vs 9,4\%). Zauważono także, iż w przypadku wystąpienia u ofiar urazów tępych świadkowie częściej podejmowali resuscytację niż w sytuacji, gdy poszkodowany doznał urazu penetrującego (9,6\% vs $5 \%)$. Znaczenie podejmowania resuscytacji przez świadków potwierdza wyliczony na podstawie analiz przywołanych badań australijskich wskaźnik przeżywalności wśród ofiar urazów. W grupie, w której świadkowie prowadzili resuscytację, wskaźnik ten wynosił średnio 5,94 $(4,11-8,58)$, dla drugiej grupy - w której świadkowie nie podjęli czynności resuscytacyjnych - wskaźnik przeżywalności wynosił średnio 2,60 (1,86-3,63) [54]. Te różnice jednoznacznie wskazują na duże znaczenie świadków i ich działań w sytuacji zatrzymania krążenia.

\section{Dysponowanie sił i środków ratownictwa}

System dysponowania sił i środków ratownictwa medycznego wpływa na udzielanie pomocy poszkodowanym w wypadkach. Stosowanie triage'u dyspozytorskiego ma na celu „wychwycenie”, w możliwie najkrótszym czasie, wezwań do ofiar wypadków, których obrażenia stanowią zagrożenie życia. Przyjęcie zgłoszenia pozwala na wstępną ocenę stopnia zagrożenia życia ofiary, identyfikację miejsca zdarzenia, w konsekwencji dając możliwość zadysponowania najbliższego (biorąc pod uwagę czas dojazdu, a nie odległość), adekwatnego do potrzeb danego zdarzenia, zespołu ratowniczego. Stosowane obecnie protokoły segregacyjne, w które wyposażony jest dyspozytor, bez wątpienia ułatwiają to zadanie. Co ważne, poprawne przyjęcie zgłoszenia minimalizuje czas reakcji (RT) systemu na zgłoszenie. W krajach wysoko rozwiniętych aktywacja systemu odbywa się zazwyczaj z jednego numeru alarmowego, np. 112. Powszechna obecnie dostępność do telefonii komórkowej, zwłaszcza w terenach wiejskich i podmiejskich, wyraźnie wpływa na skrócenie czasu aktywacji systemu, a tym samym także czas dotarcia zespołów ratowniczych na miejsce zdarzenia.

System powiadamiania ratunkowego wspierany jest obecnie dzięki upowszechnieniu automatycznej zewnętrznej defibrylacji. Dzięki automatycznym defibrylatorom z wbudowanym czujnikiem w przypadku nagłego zatrzymania krążenia i użycia automatycznego defibrylatora zewnętrznego (ang. Automated External Defibrillator, AED) przez świadków zdarzenia, możliwe jest automatyczne powiadamianie lokalnych służb ratownictwa medycznego o potrzebie interwencji. Dodatkowo aktualna lokalizacja AED jest nanoszona na mapę GIS (Systemy Informacji Przestrzennej, ang. Geographic Information System), dzięki czemu służby ratownictwa medycznego mogą uzyskać informację o lokalizacji miejsca zdarzenia.
Stwarza to warunki do szybszego dotarcia zespołów ratownictwa medycznego i wcześniejszego podjęcia czynności resuscytacyjnych. W przypadku pacjentów urazowych, szczególnie ofiar wypadku komunikacyjnego, sytuacja jest bardziej skomplikowana. Podejmowane są próby montażu w samochodach czujników, które w razie wypadku poinformują automatycznie służby ratownicze o zdarzeniu, łącznie z jego lokalizacją. Jednak tego typu rozwiązania nie są jeszcze powszechnie stosowane. Tym samym w takich sytuacjach aktywowanie systemu ratownictwa poprzez wezwanie pomocy pozostaje w rękach świadków zdarzenia.

Uzyskanie możliwie dokładnych danych o zdarzeniu możliwe jest między innymi dzięki wykorzystaniu protokołów segregacyjnych. Podejmowanie decyzji opiera się na rozmowie z osobą zgłaszającą potrzebę interwencji. Świadkowie zdarzenia, którzy zazwyczaj są pod wpływem silnych emocji, niejednokrotnie nieobiektywnie oceniają stan osób poszkodowanych. W takim wypadku istnieje ryzyko „niedosegregowania” (ang. Under-triage) lub „przesegregowania” pacjentów (ang. Over-triage). Szczególnie niebezpieczne jest zjawisko „niedosegregowania”. By zminimalizować ryzyko wystąpienia tego zjawiska, systemy segregacji dyspozytorskiej zostały opracowane z zastosowaniem tzw. „marginesu bezpieczeństwa” dla pacjenta. W razie jakichkolwiek wątpliwości co do stanu pacjenta, zdarzeniu nadawany jest wyższy priorytet. Generuje to jednak dodatkowe koszty i zwiększa ryzyko dla zespołów ratownictwa. Doświadczenia amerykańskie pokazały, iż nawet do $40 \%$ pacjentów, segregowanych tym sposobem, uzyskuje wyższy priorytet [55]. „Niedosegregowanie” z kolei, opóźnia czas dojazdu właściwych służb ratowniczych do pacjenta, co może mieć negatywne skutki zdrowotne. Dzięki temu, że współczesne systemy segregacyjne dysponują wsparciem komputerowym, pozwalają one dyspozytorowi szybciej podejmować decyzje. W części krajów (Polska, Niemcy, Francja) trudne do interpretacji wezwanie kierowane jest do zespołu kontrolnego z lekarzem ratunkowym (koordynatorem medycznym), który na podstawie analizy zgłoszenia wspiera dyspozytora w podjęciu właściwej decyzji o dysponowaniu sił i środków ratownictwa.

Prawidłowe przyjmowanie zgłoszeń i dysponowanie zespołów ratowniczych jest jednym z elementów skracających czas reakcji systemu ratownictwa na zagrożenia życia i zdrowia, bez zwiększania ryzyka dla zespołu ratowniczego i pacjenta. Ważne więc, by system wysyłania sygnałów o zdarzeniu, odbierania zgłoszenia, podejmowania decyzji i zadysponowania sił i środków wykorzystywał najnowocześniejsze technologie informatyczne. Takie innowacje bowiem, jak pokazują doświadczenia w zakresie ich stosowania, wpływają na efektywność działania systemu ratunkowego, przede wszystkim zaś na przeżywalność pacjentów, a zwłaszcza ofiar urazów.

\section{Podsumowanie}

Organizacja systemu ratowniczego ma niewątpliwie wpływ na szybkość i jakość udzielania pomocy ofiarom wypadków. Powszechnie uważa się, że czas reakcji szeroko pojętego systemu ratownictwa medycznego ma fundamentalne znaczenie. Niezależnie od poziomu udzielania 
pomocy na miejscu wypadku (BLS, ALS wykonanie prostych czynności ratujących życie, takich jak: zatamowanie krwotoków, udrożnienie dróg oddechowych, ułożenie w pozycji bezpiecznej (zapewnienie bezpieczeństwa), czy rozpoczęcie resuscytacji krążeniowo-oddechowej decyduje o przeżywalności pewnej grupy ofiar. Ważne jest więc, by przy organizacji systemów ratownictwa medycznego, wprowadzaniu nowych przepisów, czy zasad funkcjonowania systemu, ale także modyfikacji tych już obowiązujących elementy składające się na czas reakcji były uwzględniane i stanowiły punkt odniesienia dla reszty wprowadzanych rozwiązań.

\section{Literatura}

[1] Brongel L. (red.), Złota godzina. Czas życia, czas śmierci, Wydawnictwo Medyczne, Kraków 2007, 15, za: Lipiński J. (red.), Program zwalczania skutków ciężkich mnogich obrażeń ciała, MZOiS, Warszawa 1997.

[2] Trzos A., Triage in Mass Casualty Incidents, "Lek. Wojsk." Vol. 92 Issue 3, pp 298-306.

[3] Lockey D.J., Prehospital trauma management, "Resuscitation" Vol. 48, 2001, pp. 5-15.

[4] Driscoll P., Kent A., The effect of scene time on survival, "Trauma" Vol. 1, 1999, pp. 23-30.

[5] Lockey D.J., Prehospital trauma management, "Resuscitation" Vol. 48, 2001, pp. 5-15.

[6] Trunkey D.D., Trimodal Distribution of Death, "Trauma Sci Am" Vol. 249 Issue 2, 1983, p. 20.

[7] Brongel L. (red.), Złota godzina. Czas życia, czas śmierci, Wydawnictwo Medyczne, Kraków 2007.

[8] Ziegefuss T., Emergency management of polytrauma patients, "Zentrallb. Chir.” Vol. 121 Issue 11, 1996, p. 924.

[9] Baue A.E., Faist E., Multiple Organ Failure - Sumary, "Word J. Surg." Vol. 20, 1996, p. 499.

[10] Hussain L.M., Redmond A.D., Are pre-hospital deaths from accidental injury preventable? "Br Med J" Vol. 308 Issue 6936, 1994, pp. 1077-80.

[11] Papadopoulos I.N., Bukis D., Karalas E., et al., Preventable prehospital trauma deaths in a Hellenic urban health region: an audit of prehospital trauma care, "J Trauma" Vol. 41 Issue 5, 1996, pp. 864-9.

[12] Limb D., McGowan A., Fairfield J.E., Pigott T.J., Prehospital deaths in the Yorkshire Health Region, "J Accid Emerg Med", Vol. 13 Issue 4, 1996 pp. 248-50.

[13] Lemer E. B., Moscati R.M., The Golden hour: scientific fact or medical "urban legend"? "Acad Emerg Med." Vol. 8 Issue 7, 2001, pp. 758-760.

[14] Al.-Shagsi S.Z.K., Response time as a sole performance indicator in EMS: Pitfalls and solutions, "Open Asses Emergency Medicine" Vol. 2010 Issue 2, 1-6.

[15] Eisenberg M., Horwood B., Cummins R., Reynolds-Haertle R., Hearne T., Cardiac arrest and resuscitation: a tale of 29 cities, "Ann Emerg Med., Vol. 19 Issue 2, 1990, p. 179.

[16] Roth R., Stewart R., Rogers K., Cannon G., Out-of-hospital cardiac arrest: factors associated with survival, "Ann Emerg Med." Vol. 3 Issue 4, 1984, p. 237.

[17] Mullie A., Van Hoeyweghen R., Quets A., Influence of time intervals on outcome of CPR. The Cerebral Resuscitation Study Group, "Resuscitation" Vol. 17, 1989, pp. 23-33.

[18] Narad R., Driesbock K., Regulation of ambulance response times in California, "Prehosp Emerg Care" Vol. 3 Issue 2, 1999; pp. 131-135.

[19] De Maio V., Stiell I., Wells G., Spaite D., Optimal defibrillation response intervals for maximum out-of-hospital cardiac arrest survival rates, "Ann Emerg Med" Vol. 42 Issue 2, 2003, pp. 242-250.
[20] Eisenberg M., Horwood B., Cummins R., Reynolds-Haertle R., Hearne T., Cardiac arrest and resuscitation: a tale of 29 cities, "Ann Emerg Med" Vol. 19 Issue 2, 1990, p. 179.

[21] Nichol G., Stiell I., Laupacis A., Pham B., Maio V., Wells G., A cumulative meta-analysis of the effectiveness of defibrillator capable emergency medical services for victims of out-of-hospital cardiac arrest, "Ann Emerg Med" Vol. 34(4P1), 1999, pp. 517-525.

[22] Swor R., Cone D., Emergency medical services advanced life support response times: Lots of heat, little light, "Acad Emerg Med" Vol. 9 Issue 4, pp. 320-321.

[23] Pons P., Haukoos J., Bludworth W., Cribley T., Pons K., Markovchick V., Paramedic response time: Does it affect patient survival?, "Acad Emerg Med" Vol. 12 Issue 7, 2005, pp. 594-600.

[24] Pons P., Markovchick V., Eight minutes or less: does the ambulance response time guideline impact trauma patient outcome?, "J Emerg Med” Vol. 23 Issue 1, pp. 43-48.

[25] Wik L., Rediscovering the importance of chest compressions to improve the outcome from cardiac arrest, "Resuscitation" Vol. 58 Issue 3, pp. 267-269.

[26] Hazinski M., Chameides L., Elling B., American Heart Association guidelines for cardiopulmonary resuscitation and emergency cardiovascular care. Part 4: adult basic life support. Circulation, 2005, 112.

[27] Myers J.B., Slovis C.M., Eckstein M., et al., Evidence-based performance measures for emergency medical services systems: a model for expanded EMS benchmarking, "Prehosp Emerg Care" Vol. 12 Issue 2, 2008, pp. 141-151.

[28] Pell J., Sirel J., Marsden A., Ford I., Cobbe S., Effect of reducing ambulance response times on deaths from out of hospital cardiac arrest: cohort study. "Br Med J" Vol. 322(7299), 2001, pp. 1385-1388.

[29] Pons P., Markovchick V., Eight minutes or less: does the ambulance response time guideline impact trauma patient outcome?, "J Emerg Med” Vol. 23 Issue 1, 2002, pp. 43-48.

[30] Carr B.G., Caplan J.M., Pryor J.P., i in., A meta-analysis of prehospital care times for trauma, "Prehosp Emerg Care" Vol. 10 Issue 2, 2006, pp. 198-206.

[31] Blackwell T., Kaufman J., Response time effectiveness: comparison of response time and survival in an urban emergency medical services system, "Acad Emerg Med" Vol. 9 Issue 4, 2002, pp. 288-295.

[32] Department of Transport. Road accidents in Great Britain 1993: The Casualty Report. HMSO 1994.

[33] Ustawa o Państwowym Ratownictwie Medycznym z dnia 8 września 2006 r. (Dz.U. 2006 Nr 191, poz. 1410).

[34] Adnet F., Jouriles N.J., Le Toumelin P., Hennequin B., Taillandier C., Rayeh F., Couveur J., Nougiere B., Nadiras P., Ladka A., Fleury M., Survey of out-of-hospital emergency intubations in the French pre-hospital medical system: A multicenter study, "Ann Emerg Med" Vol. 32 Issue 4, 1998, pp. 454-9. 
[35] Smith R.M., Alasair K.T., Conn.: Injury, "Int. J. Care Injured" Vol. 40S4, 2009, S23-S26.

[36] Lockey D. J., Prehospital trauma management, "Resuscitation" Vol. 48, 2001, pp. 5-15.

[37] Battistella F.D., Nugent W., Owings J.T., Anderson J.T., Field triage of the pulseless trauma patient, "Arch Surg" Vol. 134, pp. 742-6.

[38] Rosemurgy A.S., Norris P.A., Olson S.M., Hurst J.M., Albrink M.H., Prehospital traumatic Cardiac arrest: the cost of futility, "J Trauma" Vol. 35, 1993, pp. 468-74.

[39] Stockinger Z.T., McSwain Jr N.E., Additional evidence in support of withholding or terminating cardiopulmonary resuscitation for trauma patients in the field, "J Am Coll Surg" Vol. 198, 2004, pp. 227-31.

[40] Hopson L.R., Hirsh E., Delgado J., Domeier R.M., McSwain Jr N.E., Krohmer J., Guidelines for withholding or termination of resuscitation in prehospital traumatic cardiopulmonary arrest: a joint position paper from the National Association of EMS Physicians Standards and Clinical Practice Committee and the American College of Surgeons Committee on Trauma, "Prehosp Emerg Care" Vol. 7, 2003, pp. 141-6.

[41] Pickens J.J., Copass M.K., Bulger E.M., Trauma patients receiving CPR: predictors of survival, "J Trauma" Vol. 58, 2005, pp. 951-8.

[42] Willis C.D., Cameron P.A., Bernard S.A, Fitzgerald M., Cardiopulmonary resuscitation after traumatic cardiac arrest is not always futile, "Injury" Vol. 37, 2006, pp. 448-54.

[43] Huber-Wagner S., Lefering R., Qvick M., i in., Outcome in 757 severely injured patients with traumatic cardiorespiratory arrest, "Resuscitation" Vol. 75, 2007; pp. 276-85.

[44] Lockey D., Crewdson K., Davies G., Traumatic cardiac arrest: who are the survivors?, "Ann Emerg Med" Vol. 48, 2006, pp. 240-4.

[45] Desy C., Bray J., Smith K. i in., Traumatic out-of-hospital cardiac arrest in Melbourne, Australia, "Resuscitation" Vol. 83, 2012, pp. 465-70.
[46] Herlitz J., Engdahl J., Svensson I., et al., Can we define patients with no chance of survival after out-of-hospital cardiac arrest?, "Heart" Vol. 90 Issue 10, 2004, pp. 1114-1118.

[47] Valenzuela T.D., Roe D.J., Cretin S., Spaite D.W., Larsen M.P., Estimating effectiveness of cardiac arrest interventions: a logistic regression survival model, "Circulation" Vol. 96, 1997, pp. 3308-13.

[48] Waalewijn R.A., de Vos R., Tijssen J.G., Koster R.W., Survival models for out-of-hospital cardiopulmonary resuscitation from the perspectives of the bystander, the first responder, and the paramedic, "Resuscitation" Vol. 51, 2001, pp. 113-22.

[49] Jockey D., Crewson K., Davies G., Traumatic Cardiac Arrest: Who are the Survivors? "Ann Emer Med”, Vol. 48 Issue 3, 2006.

[50] Pickens J.J., Copass M.K., Bulger E.M., Trauma patients receiving CPR: predictors of survival, "J Trauma" Vol. 58, 2005, pp. 951-8.

[51] Soar J., Deakin C.D., Nolan J.P., i in., European Resuscitation Council guidelines for resuscitation 2005 Section 7. Cardiac arrest in special circumstances, "Resuscitation" Vol. 67, 2005, S135-70.

[52] Willis C.D., Cameron P.A., Bernard S.A, Fitzgerald M., Cardiopulmonary resuscitation after traumatic cardiac arrest is not always futile, "Injury" Vol. 37, 2006, pp. 448-54.

[53] Callaham M., Madsen C., Relationship of timeliness of paramedic advanced life support interventions to outcome in out of hospital cardiac arrest treated by first responders with defibrillators, “Ann Emerg Med” Vol. 27 Issue 5, 1996, pp. 638-48.

[54] Desy C., Bray J., Smith K., et al., Traumatic out-of-hospital cardiac arrest in Melbourne, Australia, "Resuscitation" Vol. 83, 2012, pp. 465-470.

[55] Curka P.A., Pepe P.E., Ginger V.F., Computer aided emergency medical service priority dispatch, "Ann Emerg Med" Vol. 20, 1991, pp. 446-54.

dr n. med. Arkadiusz Trzos - specjalista chorób wewnętrznych, wykładowca, pełni funkcję kierownika Zakładu Medycyny Katastrof i Pomocy Doraźnej Uniwersytetu Jagiellońskiego Collegium Medicum. Autor wielu autorskich projektów, badań i publikacji naukowych dotyczących zarządzania i organizacji działań ratowniczych w wypadkach masowych, zagrożeniach ze strony materiałów niebezpiecznych (CBRN) oraz telemedycyny i teleinformatyki w ratownictwie.

mgr Katarzyna Długosz - doktorantka, pracuje jako asystent w Zakładzie Medycyny Katastrof i Pomocy Doraźnej Uniwersytetu Jagiellońskiego Collegium Medicum. Autorka badań i publikacji naukowych dotyczących tematyki ratownictwa medycznego, edukacji medycznej, zarządzania w ratownictwie. W swoich pracach porusza także problematykę niepełnosprawności i integracji społecznej. 